selective IgA deficiency is more common among Jews than among other ethnic groups cannot be ruled out. It seems more likely, however, that the higher prevalence of selective IgA deficiency in the present series was related to the criteria for selection of patients to be examined.

Selective IgA deficiency has been detected mainly among patients with recurrent infections, "autoimmune" disorders, or malabsorption, but also among asymptomatic individuals (Bachman, 1968; Claman et al., 1966; Johansson et al., 1968; Cassidy et al., 1968). The nature of the associated diseases in our patients with selective IgA deficiency was in general similar to that reported in the literature, but for the high incidence of hepatitis. At the time of diagnosis two patients had acute hepatitis, one had a documented history of this disease, one had chronic persistent hepatitis, and one had chronic active hepatitis.

IgA is believed to play an important part in protecting the gastrointestinal tract. Symptoms referrable to the gut, mainly malabsorption with steatorrhoea, have been observed in patients with selective IgA deficiency (Hobbs, 1968; Crabbé and Heremans, 1967; Ammann and Hong, 1971). IgA-producing plasmacytes are dominant among the lymphoid cells of the lamina propria (Crabbé and Heremans, 1967), and evidence has been presented that IgA antibodies have viral neutralizing activity (Rossen et al., 1965). Specific secretory IgA antibody to the hepatitis-associated antigen has indeed been detected in the mucosal surface by Ogra (1973). It seems likely, therefore, that a defect in the normal protective action of $\operatorname{IgA}$ in the alimentary tract, combined with a mild defect in humoral immunity, could result in a higher tendency to infections by viruses, the portal of entry of which is the gut.

We are not aware of any previous reports of a higher susceptibility of patients with selective IgA deficiency to viral hepatitis. "Lupoid" hepatitis, however, has been reported so far in five patients with selective IgA deficiency (Ammann and Hong, 1971), and one of our patients had chronic aggressive hepatitis. It is conceivable that the "immunological imbalance," postulated by Hobbs (1968) in patients with selective IgA deficiency, together with their increased susceptibility to viral hepatitis, could lead to the development of chronic aggressive hepatitis in some cases.

This study was supported by grants from the Joint Research Fund of the Hebrew University and Hadassah University Hospital and Medical Sahool and the Israel Cancer Association.

We wish to thank Professor $M$. Eliakim for his valuable comments.

\section{References}

Ammann, A. J., and Hong, R. (1971). Medicine, 50, 223. Investigation, 17 . Scan

Investigation, 17, 316 .
sidy, J. T., Burt, A., Petty, R., and Sullivan, D. (1968). New England Fournal of Medicine, 280, 275.

Claman, H. N., Hartley, T. F., and Merrill, D. (1966). Fournal of Allergy, 38,215 .

Crabbé, P. A., and Heremans, J. E. (1967). American fournal of Medicine, 42, 319.

Hobbs, J. R. (1968). Lancet, 1, 110.

Johansson, S. G. O., Hogman, C. F., and Killander, J. (1968). Acta Pathologica et Microbiologica Scandinavica, 74, 519.

Mancini, G., Carbonara, A. O., and Heremans, J. F. (1965). Immunochemistry, 2, 235.

Ogra, P. L. (1973). Fournal of Immunology, 110, 1197.

Rossen, R. D., Butler, W. T., Cate, T. R., Szwed, C. F., and Couch, R. B. (1965). Proceedings of the Society for Experimental Biology and Medicine, (1965). Proceedings of the Society for Experimental Biology and Medicine,

Scheidegger, J. J. (1955). International Archives of Allergy and Applied Immunology, 7, 103.

Tomasi, T. B. (1968). New England Fournal of Medicine, 279, 1327.

\title{
Therapeutic Non-equivalence of Digoxin Tablets in the United Kingdom: Correlation with Tablet Dissolution Rate
}

\author{
T. R. D. SHAW, K. RAYMOND， M. R. HOWARD, JOHN HAMER
}

British Medical fournal, 1973, 4, 763-766

\section{Introduction}

\section{Summary}

Seven types of digoxin $0.25 \mathrm{mg}$ tablet in common use in the United Kingdom were administered to a total of 38 patients. Significant differences were found in the mean plasma digoxin levels and in the control of atrial fibrillation achieved with these brands. There was a close correlation between the dissolution rate of the tablets and the plasma digoxin levels. Measurement of in-vitro dissolution rate appears to be a valid method of ensuring that different tablets of digoxin are of equal efficacy. However, in some patients absorption of the drug is markedly sensitive to changes in dissolution rate and new pharmacopoeal standards should not be defined until very rapidly-dissolving formulations have been studied.

\footnotetext{
Department of Cardiology, St. Bartholomew's Hospital, London EC1A 7BE

T. R. D. SHAW, M.R.C.P., Registrar

JOHN HAMER, F.R.C.P., Consultant Cardiologist

Department of Pharmaceutics, School of Pharmacy, University of London, London W.C.1

K. RAYMOND, M.PHARM., Lecturer
}

It has become apparent that tablets of digoxin may contain the correct dose but provide only a portion of this dose for absorption by the patient. Reports from several countries have shown wide variation in absorption between different brands of tablets and even between different batches of the same brand (Lindenbaum et al., 1971; Manninen et al., 1971; Bertler et al., 1972; Shaw et al., 1972). These differences are not detected by the test for disintegration rate given in the British and U.S. pharmacopoeias (Shaw et al., 1972; Wagner et al., 1973).

We have administered to patients seven different types of digoxin tablet used in the United Kingdom and have recorded the plasma digoxin levels and clinical response obtained with each type. The digoxin level and response have been compared with the dissolution rate of the tablets to assess the validity of measurement of dissolution rate as an in-vitro test for quality control of digoxin tablet manufacture.

\section{Patients and Methods}

Of the two groups of 20 patients studied 19 of each group completed the period of study (table I). 
TABLE I-Characteristics of Patients in Group 1 and Group 2. (Means \pm S.D.)

\begin{tabular}{|c|c|c|c|c|c|c|c|c|}
\hline & \multicolumn{2}{|c|}{$\begin{array}{l}\text { No. and } \\
\text { Sex }\end{array}$} & $\begin{array}{c}\text { Age } \\
\text { (years) }\end{array}$ & $\begin{array}{c}\text { Weight } \\
(\mathbf{K} \mathbf{g})\end{array}$ & $\underset{(\mathrm{cm})}{\text { Height }}$ & \multirow{2}{*}{$\frac{\begin{array}{c}\text { Urea } \\
(\mathrm{mg} / 100 \mathrm{ml})\end{array}}{36 \cdot 8 \pm 12 \cdot 4}$} & \multirow{2}{*}{$\begin{array}{c}\begin{array}{c}\text { Serum Creatinine } \\
(\mathrm{mg} / 100 \mathrm{ml})\end{array} \\
1.06 \pm 0.20 \\
1.01 \pm 0.23\end{array}$} & \multirow{2}{*}{ 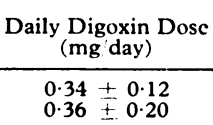 } \\
\hline $\begin{array}{l}\text { Group } 1(n=19) \\
\text { Group } 2(n=19)\end{array}$ & $\begin{array}{l}14 \mathrm{~F} . \\
15 \mathrm{~F} .\end{array}$ & $\begin{array}{l}5 \mathrm{M} . \\
4 \mathrm{M} .\end{array}$ & $\begin{array}{l}59 \cdot 4+6 \cdot 7 \\
57 \cdot 2 \div 8 \cdot 1\end{array}$ & $\begin{array}{l}61.9+10 \cdot 1 \\
63.5 \pm 11 \cdot 3\end{array}$ & $\begin{array}{r}159 \cdot 6+21 \cdot 7 \\
164.7+8.9\end{array}$ & & & \\
\hline
\end{tabular}

TABle II-Mean Plasma Digoxin Levels ( \pm S.D.) Recorded during Use of Seven Different Types of Digoxin Tablet. Figures in Parentheses are Mean Levels expressed as Proportion of Newer Lanoxin

\begin{tabular}{|c|c|c|c|c|c|c|c|c|}
\hline & $\begin{array}{l}\text { Brand and } \\
\text { Batch No.: }\end{array}$ & $\begin{array}{c}\text { Newer Lanoxin } \\
(\text { B.N. 1579X) }\end{array}$ & $\begin{array}{l}\text { Nativelle } \\
\text { (B.N. 369) }\end{array}$ & $\begin{array}{c}\text { Boots } \\
(B . N .12 \mathrm{~N})\end{array}$ & $\begin{array}{l}\text { Older Lanoxin } \\
\text { (B.N. 0953X) }\end{array}$ & $\begin{array}{l}\text { Macarthy's } \\
\text { (B.N. S2435) }\end{array}$ & $\begin{array}{l}\text { Oppenheimer } \\
\text { (B.N. 30005) }\end{array}$ & $\begin{array}{c}\text { Cox } \\
\text { (B.N. 212051) }\end{array}$ \\
\hline $\begin{array}{l}\text { Group } 1 \\
\text { Group } 2\end{array}$ & $\begin{array}{l}\cdots \\
\cdots\end{array}$ & $\begin{array}{c}1.30+0.51 \\
(100) \\
1.01+0.32 \\
(100)\end{array}$ & $\begin{array}{c}1.20+0.47 \\
(92)\end{array}$ & $\begin{array}{c}1.02 \pm 0.40 \\
(78) \\
-\end{array}$ & $\begin{array}{c}0.91+0.45 \\
(70) \\
-\end{array}$ & $\begin{array}{c}- \\
0.92+0.35 \\
(91)\end{array}$ & $\begin{array}{c}- \\
0 \cdot 82+0 \cdot 28 \\
(81)\end{array}$ & $\begin{array}{c}- \\
0 \cdot 75+0 \cdot 27 \\
(74)\end{array}$ \\
\hline
\end{tabular}

Each patient used four different types of digoxin $0.25 \mathrm{mg}$ tablet, each type for a two-week period. The sequence was randomized. The dosage of digoxin was constant for each patient. The patients were asked to take the daily dose in the latter half of the evening and at the same time each day.

Blood samples were taken at the end of each two-week period and plasma digoxin was measured by radioimmunoassay (Chamberlain et al., 1970). To avoid the absorptive and distribution phases blood was always taken more than 10 hours after the last dose. The mean interval since the last dose was 13 hours (range 10-17 hr) and was approximately constant for each patient. A 30-second E.C.G. rhythm strip at rest was recorded on each visit.

The number of tablets supplied to each patient was known, and from a count of the unused tablets the discrepancy in self-administration was estimated. The patient's other medication was unchanged throughout the time of the study.

Digoxin Tablets. - The brand name and batch number of the tablets used are included in table II. The brands were chosen to provide a range of dissolution rates. Two types of the Lanoxin (Burroughs Wellcome) brand were studied. The "newer.Lanoxin" were manufactured since the recent change in the production method of this brand (British Medical fournal, 1972; Shaw et al., 1973 a). The "older Lanoxin" were produced shortly before the change. Both groups of patients used the same batch of newer Lanoxin to allow comparison between the groups. All brands met the British Pharmacopoeia (1968) standard for digoxin content of 20 tablets.
Disintegration and Dissolution Rates.-Disintegration time was measured by the method of the British Pharmacopoeia (1968). The method used for determining the dissolution rate was that of the U.S. Pharmacopeia (1970) using $600 \mathrm{ml}$ of distilled water; the basket was rotated at 120 r.p.m. Samples were removed at $15,30,45,60,90$, and 120 minutes. After filtering (Millipore, $0.45 \mu \mathrm{m}$ pore size) digoxin content was measured by a fluorimetric method (Jensen, 1953). Six tablets were used for measurement of dissolution rate and for each batch the test was repeated on three separate occasions.

\section{Results}

The mean plasma digoxin levels obtained with the seven types of tablet are given in table II. To permit comparison between all types the levels achieved with the newer Lanoxin have been taken as 100 and the other mean levels expressed as a proportion of this figure. The levels found with newer Lanoxin were $43 \%$ higher than those recorded with the tablets (older Lanoxin) which produced lowest levels. Analysis of variance showed that the differences within each group were statistically significant $(P<0 \cdot 1)$.

The discrepancy in the tablet count of each type was always small $(<3 \%)$ and was similar for each type of tablet within the two groups.

Thirteen patients in each group had atrial fibrillation. The ventricular rates and digoxin levels recorded in these patients during the different digoxin treatments are given in table III.

TABLE III-Mean Resting Ventricular Rates and Plasma Digoxin Levels ( \pm S.D.) in Patients with Atrial Fibrillation.

\begin{tabular}{|c|c|c|c|c|c|c|c|}
\hline Brand: & Newer Lanoxin & Nativelle & Boots & Older Lanoxin & Macarthy's & Oppenheimer & Cox \\
\hline $\begin{array}{l}\text { Group } 1(n=13): \\
\text { Ventricular rate } . . \\
\text { Plasma digoxin } . . \\
\text { Group } 2(n=13): \\
\text { Ventricular rate } . . \\
\text { Plasma digoxin .. }\end{array}$ & $\begin{array}{l}74.9 \pm 17.1 \\
1.36 \pm 0.56 \\
82.3 \pm 18.7 \\
1.08 \pm 0.33\end{array}$ & $\begin{array}{c}79 \cdot 1+16.6 \\
1 \cdot 28 \pm 0.50 \\
= \\
-\end{array}$ & $\begin{array}{c}83.7 \pm 16.8 \\
1.10 \pm 0.43 \\
= \\
-\end{array}$ & $\begin{array}{c}84 \cdot 5+19 \cdot 2 \\
1 \cdot 00 \pm 0 \cdot 47 \\
- \\
-\end{array}$ & $\begin{array}{c}\text { 二 } \\
81 \cdot 7+26 \cdot 4 \\
0.94+0.36\end{array}$ & $\begin{array}{c}\text { 二 } \\
89.5 \pm 20.5 \\
0.86 \pm 0.26\end{array}$ & $\begin{array}{c}\text { 二 } \\
89.4+17.6 \\
0.81 \pm 0.27\end{array}$ \\
\hline
\end{tabular}

TABLE IV-Dissolution and Disintegration Rates of Seven Types of Digoxin Tablet. Correlation Coefficients Relate to Percentage of Stated Dose in Solution at Each Time Interval and Mean Plasma Digoxin Level Relative to that of Newer Lanoxin

\begin{tabular}{|c|c|c|c|c|c|c|c|c|c|c|}
\hline & & & & \multicolumn{6}{|c|}{ Dissolution Rate } & \multirow{3}{*}{$\begin{array}{l}\text { Disintegration } \\
\text { Time } \\
\text { (min) }\end{array}$} \\
\hline \multirow{2}{*}{\multicolumn{4}{|c|}{ Brand }} & \multicolumn{6}{|c|}{ Percentage of Stated Dose in Solution at: } & \\
\hline & & & & $15 \mathrm{~min}$ & $30 \mathrm{~min}$ & $45 \mathrm{~min}$ & $60 \mathrm{~min}$ & $90 \mathrm{~min}$ & $120 \mathrm{~min}$ & \\
\hline $\begin{array}{l}\text { Newer Lanoxin } \\
\text { Nativelle } \\
\text { Macarthy's . . } \\
\text { Oppenheimer } \\
\text { Boots .. . } \\
\text { Cox . . } \\
\text { Older Lanoxin }\end{array}$ & $\begin{array}{l}\ldots \\
\because \\
\cdots \\
\cdots\end{array}$ & $\begin{array}{l}. \\
\because \\
\because \\
\because \\
\cdots\end{array}$ & $\begin{array}{l}\ldots \\
\cdots \\
\cdots \\
\cdots \\
\cdots \\
\end{array}$ & $\begin{array}{l}62 \\
42 \\
36 \\
39 \\
22 \\
24 \\
27\end{array}$ & $\begin{array}{l}86 \\
57 \\
48 \\
44 \\
32 \\
32 \\
37\end{array}$ & $\begin{array}{l}94 \\
62 \\
53 \\
51 \\
42 \\
37 \\
45\end{array}$ & $\begin{array}{r}100 \\
67 \\
57 \\
52 \\
41 \\
38 \\
48\end{array}$ & $\begin{array}{r}104 \\
70 \\
63 \\
55 \\
47 \\
41 \\
54\end{array}$ & $\begin{array}{r}106 \\
73 \\
65 \\
60 \\
52 \\
44 \\
54\end{array}$ & $\begin{array}{l}<2 \\
<1 \\
<4 \\
<3 \\
<5 \\
<2 \\
<3\end{array}$ \\
\hline \multicolumn{4}{|c|}{ 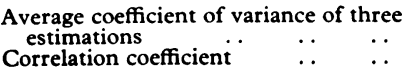 } & $\begin{array}{c}22.9 \\
0.87\end{array}$ & $\begin{array}{l}5 \cdot 5 \\
0 \cdot 89\end{array}$ & $\begin{array}{l}9 \cdot 5 \\
0.86\end{array}$ & $\begin{array}{l}5 \cdot 6 \\
0 \cdot 87\end{array}$ & $\begin{array}{l}5 \cdot 5 \\
0.86\end{array}$ & $\begin{array}{l}5 \cdot 0 \\
0 \cdot 88\end{array}$ & $=$ \\
\hline
\end{tabular}


These differences are statistically significant (analysis of variance, $\mathrm{P}<0.01$ ).

The dissolution rates of the tablets are given in table IV and fig. 1. The disintegration rate of each type of tablet is shown in table IV. This table also gives the linear correlation coefficient between the percentage of stated dose in solution at each time of sampling and the plasma digoxin level obtained with each type relative to that of the newer Lanoxin. A good correlation was found at each period (range 0.86-0.89). The relation between plasma level and percentage in solution at 30 minutes is shown in fig. 2.

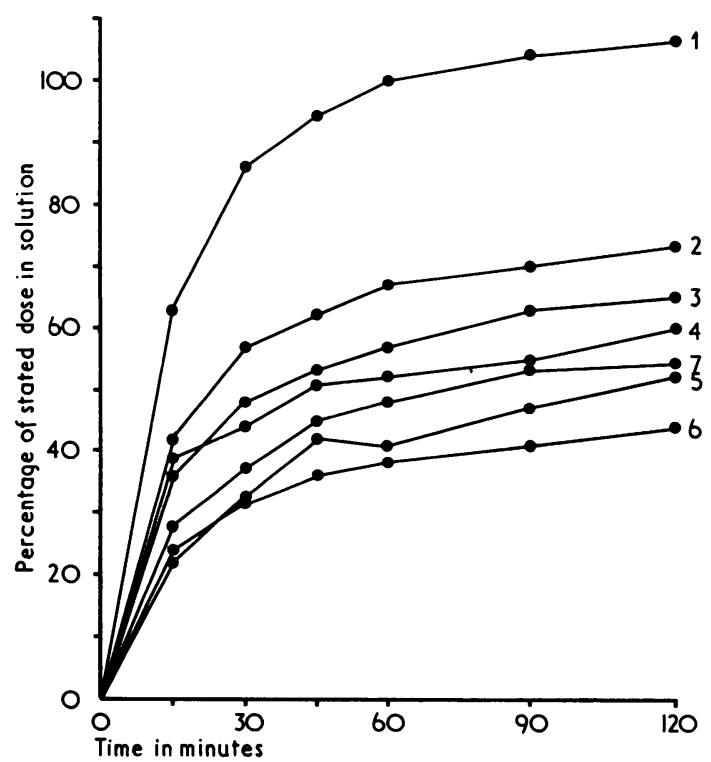

FIG. 1-Dissolution rates of the seven types of digoxin tablet. $1=$ Newer Lanoxin. $2=$ Nativelle. $3=$ Macarthy's. $4=$

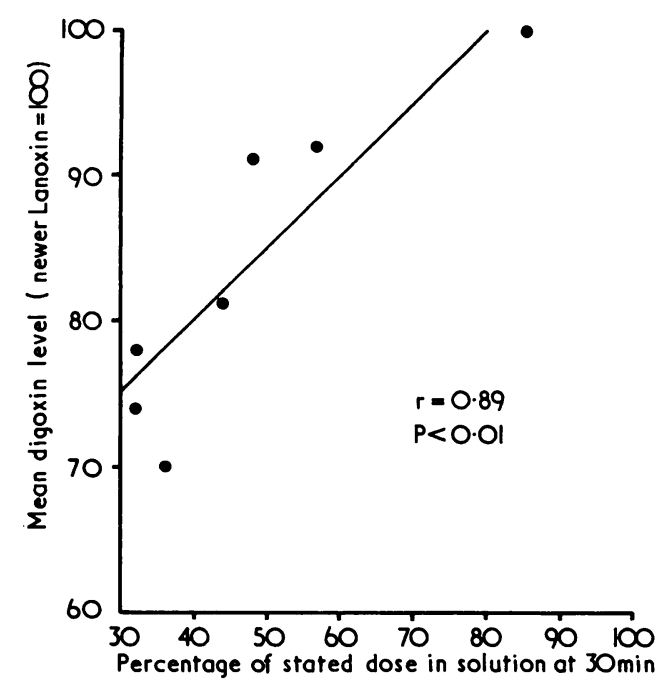

FIG. 2-Relation between percentage dissolution at 30 minutes and plasma digoxin level. Mean digoxin level obtained with newer Lanoxin $=100$, and levels found with other brands expressed as a proportion of this figure. $\mathrm{Y}=59 \cdot 3+0.5 \mathrm{x}$.

Some patients appeared to be much more sensitive than others to change in the dissolution of their tablets. The change in digoxin level in two patients from the second group who had both taken $0.5 \mathrm{mg}$ digoxin per day is shown in fig. 3 . Both had normal blood urea and serum creatinine and were of similar weight. Patient A absorbed digoxin poorly from the slowly-dissolving tablets but had a marked increase in plasma digoxin level when changed to the faster-dissolving tablets: patient $\mathbf{B}$ had a higher digoxin level with slowlydissolving tablets and showed only a moderate increase during use of the faster-dissolving brands.

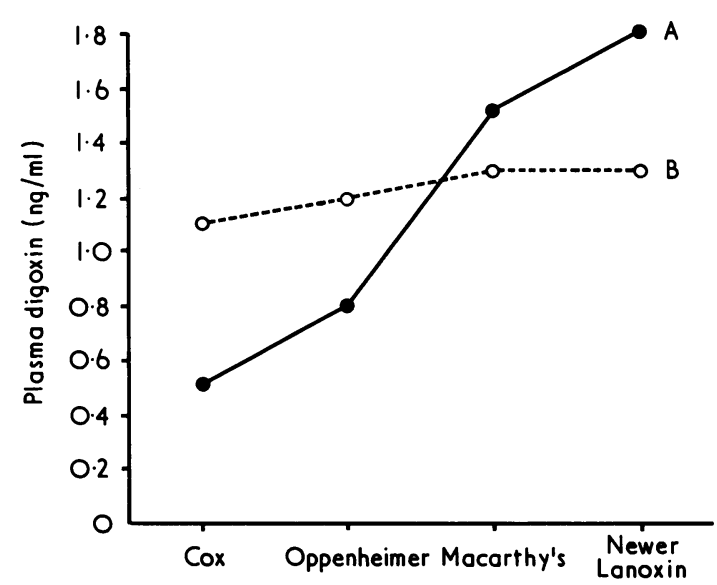

FIG. 3-Plasma digoxin levels recorded in two patients of similar size and normal renal function during use of $0.5 \mathrm{mg}$ / day of four different brands of tablet.

\section{Discussion}

Difficulties in formulations of the digitalis glycosides are not new. Withering (1785) noted that the efficacy of the foxglove leaves varied according to the season and age of the plants, and observed that some physicians had avoided toxicity by using relatively inent roots.

With the introduction of digoxin it was hoped that a more consistent preparation would be possible (Wayne, 1933). Later, however, Gold et al. (1953) noted the difference in the recommended doses of digoxin and suggested that this might reflect variation in the preparations used. Occasional cases were reported where parenteral doses were much more effective than administration by mouth (Craig et al., 1958).

It has now become clear that wide variation in the absorption of digoxin may result from differences in the type of tablet used. This variation appears to be due to the effect of the production methods on the particle size of the digoxin (Shaw et al., 1973 b). Our results confirm that there are important differences in the steady-state plasma digoxin levels achieved during maintenance treatment with different types of $0.25 \mathrm{mg}$ digoxin tablets available in the United Kingdom. They slightly underestimate the magnitude of difference since some patients with very poor absorption of digoxin from slowly-dissolving tablets were already investigated and not included in this study (Shaw et al., 1972, 1973 b). Digoxin levels recorded six to 24 hours after the last dose have been found to correlate with the clinical effect and toxicity of digoxin (Smith, 1972). These differences render treatment with digoxin more hazardous since the dose found to be satisfactory with one brand may produce toxicity or underdigitalization when the patient later receives tablets of another brand. Measurement of plasma digoxin levels in cardiac patients after a suitable period of maintenance dosage is probably the most clinically relevant means of quantitating differences in the efficacy of tablets. Differences have also been found in the peak levels and the areas under absorption curves in single-dose studies: these indices appear to be very sensitive ways of detecting non-equivalence of formulations but produce differences larger than those recorded after 
periods of daily digoxin administration (Lindenbaum et al., 1971; Falch et al., 1973; Lindenbaum et al., 1973).

Differences were also seen in the clinical response to the digoxin treatment in patients with atrial fibrillation. The variation in mean ventricular rate underestimates the non-equivalence of clinical response in individual patients since some patients tend to have persistently slow ventricular rates at rest even when not using digitalis.

Despite the differences in biological availability of the tablets studied, all passed the test for disintegration time given in the British Pharmacopoeia. This test, which measures the time taken by the tablets to fragment, is now regarded as an inadequate means of preventing non-equivalence of brands of tablet. The dissolution rate measures the rate at which the drug enters solution and estimates a property of tablets more directly related to the needs of absorption. Our data show that there is a close correlation between the digoxin level achieved in patients during maintenance therapy and the dissolution rate of the tablets used, even when the tablets are produced by various manufacturing methods and contain a variety of combinations of excipient substances. Similar correlation between fissolution rate and steady-state levels in normal volunteers have been found by Lindenbaum et al. (1973) and Johnson et al. (1973). We have found appreciable batch-to-batch variation in dissolution rate of some of the brands studied (Shaw, 1973), indicating that keeping to the use of one brand will not always guarantee consistent bioavailability.

Lindenbaum et al. (1973) and Johnson et al. (1973) proposed that a minimal acceptable level of dissolution rate be established. It appears that a dissolution rate of greater than $80 \%$ at 1 hour would ensure that variation was less than $0.1 \mathrm{ng} / \mathrm{ml}$ in the mean digoxin level of a group of subjects. However, some patients show a pronounced rise in plasma digoxin level when the dissolution rate of their tablets is increased, and are at risk from even moderate degrees of variation between tablets. Others absorb digoxin well even from slowlydissolving tablets. These differences between subjects, which have also been observed in other studies (Shaw et al., 1972, 1973; Falch et al., 1973), may reflect individual variation in gastrointestinal transit time. A similar variation between patients is known for a variety of drugs which, like digoxin, are poorly soluble (Levy, 1968). The sensitivity of some patients to differences in the rate of dissolution of the tablets means that standards designed to ensure the therapeutic equivalence of digoxin tablets for all patients should be as strict as possible.

The linear relation between absorption and dissolution rate is unlikely to continue indefinitely since only $100 \%$ of the dose can ultimately be absorbed. With progressively faster dissolution rates the amount absorbed could reach a plateau, and our data and those of Johnson et al. (1973) show a tendency for the increase in digoxin level to reach a plateau at dissolution rates of about $100 \%$ at 1 hour and $85 \%$ at 30 minutes. Standards for acceptable dissolution rates should specify a minimum dissolution rate within the plateau part of relationship. We conclude that the in-vitro measurement of dissolution rate will be a satisfactory way of ensuring the required consistency between brands of digoxin tablet (Hamer and Grahame-Smith, 1972), but further study of rapidly-dissolving tablets is required before standards can be defined.

We should like to express our thanks to Mr. Pravin Patel for help with the in-vitro studies, and to Miss Marion Hodges and Miss Jean Rossi. We are grateful to Mr. D. M. MoCulloch for carrying out the statistical analysis. M.R.H. is in receipt of a British Heart Foundation grant.

Requests for reprints should be addressed to: Dr. T. R. D. Shaw, Department of Cardiology, St. Bartholomew's Hospital, London EC1A 7BE.

\section{References}

Bertler, A., Redfors, A., Medin, S., and Nyberg, L. (1972). Lancet, 2, 708. British Medical Fournal, 1972, 3, 427.

British Pharmacopoeia (1968). London, Pharmaceutical Press.

Chamberlain, D. A., White, R. J., Howard, M. R., and Smith, T. W. (1970). British Medical fournal, 3, 429.

Craig, L. C., Lown, B., and Levine, S. A. (1958). fournal of the American Medical Association, 166, 2139 .

Falch, D., Teien, A., and Bjerkelund, C. J. (1973). British Medical fournal,

Gold, H., et al. (1953). Fournal of Pharmacology and Experimental Therapeutics, $109,45$.

Hamer, J., and Grahame-Smith, D. G. (1972). Lancet, 2, 325.

Jensen, K. B. (1953). Acta Pharmacologia et Toxicologica, 9, 66.

Johnson, B. F., Greer, H., McCrerie, J., Bye, C., and Fowle, A. (1973). Lancet, 1,1473 .

Levy, G. (1968). In Physico-Chemical Aspects of Drug Action, ed. E. J. Ariens, p. 33. Oxford, Pergamon Press. Lindenbaum, V., Mellow, M. H., Blackstone, M. O., and Butler, V. P.
(1971). New England fournal of Medicine, 285, 1344.

Lindenbaum, J., Butler, V. P., Murphy, J. E., and Cresswell, R. M. (1973). Lancet, 1,1215 .

Manninen, V., Melin, J., and Härtel, G. (1971). Lancet, 2, 934.

Shaw, T. R. D., Howard, M. R., and Hamer, J. (1972). Lancet, 2, 303.

Shaw, T. R. D. (1973). Postgraduate Medical fournal. In press.

Shaw, T. R. D., Howard, M. R., and Hamer, J. (1973 a). British Heart fournal. In press.

fournal. In press.
Shaw, T. R. D., Carless, J. E., Howard, M. R., and Raymond, K. (1973 b). Lancet, 2, 209 .

Smith, T. W. (1972). Circulation, 46, 188.

U.S. Pharmacopeia (1970). 18th edn., p. 934. New York, U.S. Pharmacopeia Convention Inc. Wagner, J. G., et al. (1973). Fournal of the American Medical Association,
224, 199.

Wayne, E. J.(1933). Clinical Science, 1, 63.

Withering, W. (1785). In An Account of the Foxglove, and Some of its Medicinal Uses: with Practical Remarks on Dropsy and other Diseases. Reprinted in Classics of Cardiology 